\title{
A Study on Physico Chemical Water Quality Parameters of Brahmpur Pond, Buxar, Bihar
}

\author{
${ }^{1}$ Arvind Kumar Rai
}

\begin{abstract}
:
The water samples collected from the selected pond were analyzed at specific time intervals in the month of February, April and June in year 2020. The parameter studied were namely Temperature, pH, DO, TDS, TSS, Alkalinity, Hardness and Chloride. The study showed that the Shatabdi pond is unfit for drinking, bathing or household purposes. The result obtained in the present investigation revealed that the Shatabdi pond is polluted.
\end{abstract}

Key Words: Water, pH, Oxygen content, Hardness, Chloride

Corresponding Author: ' Arvind Kumar Rai, Lecturer Department of Environment Chemistry, Garhwa Polytechnic, Garwah, Jharkhand.Email; dolphinarvind@gmail.com

\section{Introduction:}

Water is essential for the survival of any form of life. Water plays an important role in the development of healthy society. It is the most abundant and most useful compound in the world and hence it is called 'Amrit in Sanskrit. Water accounts for about $70 \%$ of the weight of a human body. Generally, a human being consumes about 3 liters of water. About $80 \%$ of the earth surface is covered by water. Out of estimated 1,011 million $\mathrm{km}^{2}$ of the total water present on earth, only $33,400 \mathrm{~m}^{3}$ of water is available for drinking, agriculture, domestic and industrial consumption [1]. Ponds have been used since time immemorial as a traditional source of water supply in India. A pond is referred to as a man made or natural water body which is between $2 \mathrm{~m} 2$ and 3 ha in area. Which hold water for four month of the year.

Pollution of water bodies is increasing steadily due to rapid population growth, industrial development, urbanization, increasing use of pesticides and wide activities of human beings. Some pollutants do not easily dissolve in water. Some suspended pollutants later settle under the water body. This can harm and even kill aquatic life that live at the floor of water bodies. Some wastewater, fertilizers and sewage contain high levels of nutrients [2]. If they end up in water bodies, such as pond, lake, swamps they encourage algae and weed growth in the water. This will make the water undrinkable and affect the whole ecosystem. A large amount of algae will 
also use up all the oxygen in the water bodies and other microbes in the water will die out of oxygen from starvation. Table 1- gives the drinking water quality standards as per IS: 10500-1991[3].

Table 1. Drinking Water Quality Standards (IS: 10500-1991)

\begin{tabular}{|c|c|c|c|}
\hline S. No & Parameters & Range & Effects \\
\hline \multicolumn{4}{|c|}{ Physical } \\
\hline 1 & $\begin{array}{l}\text { Turbidity, Units on } \\
\text { J.T.U scale }\end{array}$ & 2.5 & $\begin{array}{l}\text { Undesirable effects on human } \\
\text { beings }\end{array}$ \\
\hline 2 & Color & 5.0 & $\begin{array}{l}\text { Undesirable effects on human } \\
\text { beings }\end{array}$ \\
\hline 3 & $\begin{array}{l}\text { Taste and Odor, } \\
\text { Units on Platinum } \\
\text { cobalt scale }\end{array}$ & Unobjectionable & $\begin{array}{l}\text { Undesirable effects on human } \\
\text { beings }\end{array}$ \\
\hline \multicolumn{4}{|c|}{ Chemical } \\
\hline 4 & $\mathrm{pH}$ & $6.5-8.5$ & $\begin{array}{l}\text { Beyond this range the water will } \\
\text { affect water supply system and } \\
\text { mucous membrane }\end{array}$ \\
\hline 5 & Total hardness & 300 & Adverse effect on domestic use \\
\hline 6 & Iron & 0.3 & Adverse effect on human health \\
\hline 7 & Chlorides & 250 & $\begin{array}{l}\text { Cause Taste, corrosion and } \\
\text { palatability are affected }\end{array}$ \\
\hline 8 & $\begin{array}{l}\text { Residual free } \\
\text { chlorine }\end{array}$ & 0.2 & -- \\
\hline 9 & Dissolved solids & 500 & Cause gastrointestinal irritation \\
\hline 10 & Nitrates & 45 & $\begin{array}{l}\text { Beyond this methaemoglobinemia } \\
\text { may be caused in infants. }\end{array}$ \\
\hline 11 & Fluoride & 1.0 & Cause fluorosis \\
\hline
\end{tabular}




\begin{tabular}{|l|l|l|l|}
\hline 12 & Alkalinity & 200 & $\begin{array}{l}\text { Beyond this water becomes } \\
\text { unpleasant }\end{array}$ \\
\hline 13 & $\begin{array}{l}\text { PAH, Hexavalent } \\
\text { chromium }\end{array}$ & 0.01 & May be carcinogenic \\
\hline $\mathbf{1 4}$ & Pesticides & Absent & Very toxic \\
\hline $\mathbf{1 5}$ & Heavy metals & 0.001 & Becomes more toxic \\
\hline
\end{tabular}

Source: Based on IS: 10500-1991

\section{Materials and Methods:}

Study Area: Brahmpur pond is located near the Brahmeshwarnath Temple which is considered to be the most sacred places of Lord Shiva. It is an important Hindu pilgrimage centre of Bihar state. It is situated $35 \mathrm{~km}$ from Buxar town, Bihar. A perennial water source, it attracts birds, both native and migratory, to quench their thirst and breed at its banks. At present, it serves as a massive water system for local villagers. The water of this pond is used all year round to domestic purposes or drinking purposes. The calm surface of the pond provides an ideal place for worship. Various domestic, shops or urban sources are located on the bank of this pond and cloth, paper, wood, \& plastic waste is disposed off into the pond at regular intervals.

The water samples were collected in the cleaned, air tight water glass bottle and taken to the laboratory for analysis as per guidelines of APHA, 1995 [4]. The water samples were transported under ice cooled conditions with appropriates sealing. The water of ponds is polluted mainly due to discharged waste water from area, sewage outlets of nearby shops, solid wastes, \& detergents.

\section{Results and Discussion:}

Table 3. Physico Chemical Water Quality Parameters of Brahmpur Pond, Buxar

\begin{tabular}{|l|l|l|l|}
\hline S.No & $\begin{array}{l}\text { Water Quality } \\
\text { Parameters/units }\end{array}$ & Methods & Range \\
\hline 1 & Water temperature, $0^{\mathrm{C}}$ & $\ldots$ & $25-31$ \\
\hline
\end{tabular}




\begin{tabular}{|l|l|l|l|}
\hline 2 & $\mathrm{pH}$ & Potentiometer & $7.32-7.75$ \\
\hline 3 & DO, mg/l & Winkler's method & $2.71-3.64$ \\
\hline 5 & TDS, mg/l & Gravimetric method & $138-148$ \\
\hline 6 & TSS, mg/l & Gravimetric method & $32.44-104.32$ \\
\hline 7 & Alkalinity, mg/l & Titration & $212.0-347.0$ \\
\hline 8 & Hardness, mg/l & EDTA method & $82.1-135.3$ \\
\hline 9 & Chloride, $\mathrm{mg} / \mathrm{l}$ & $\begin{array}{l}\text { Potentiometer, } \\
\text { Titration }\end{array}$ & $71.44-164.2$ \\
\hline
\end{tabular}

Source: Authors own study

Water Temperature: The temperature of water has very important ecological effects. Temperature exerts a major influence on aquatic flora and fauna with respect to occurrence and level of activity of the aquatic flora and fauna [5]. In general, increasing water temperature results in greater biological activity and more rapid growth. All aquatic organisms have preferred temperature in which they can survive and reproduce optimally. The levels of water temperature in the present study were ranging from $25^{\circ} \mathrm{C}$ (minimum) to $31^{\circ} \mathrm{C}$ (maximum) from all the selected sampling points.

$\mathrm{pH}: \mathrm{pH}$ of the aquatic system is an important indicator of the water quality and the extent pollution in the watershed areas. In the present investigation, $\mathrm{pH}$ was recorded to be varying from 7.32 to 7.75 . It has been mentioned that the increasing $\mathrm{pH}$ appear to be associated with increasing use of soap, detergents in residential areas [6]. The result of $\mathrm{pH}$ value indicated that Brahmpur pond is alkaline in nature.

DO: Oxygen saturation in the environment refers to the amount of oxygen dissolved in the soil or water bodies. Water bodies have different types of micro-organisms. These include aerobic and anaerobic organisms. When too much biodegradable matter end up in water bodies, it encourages more microorganism growth, and they use up more oxygen in the water. If oxygen is depleted, aerobic organisms die, and anaerobic organism grow more to produce harmful toxins such as ammonia and sulfides. The optimal levels in an estuary or fresh water body for dissolved oxygen 
(DO) are higher than $6 \mathrm{ppm}$. [7]. In the present study, DO varied $2.71 \mathrm{mg} /$ litre to 3.64 $\mathrm{mg} / \mathrm{litre}$.

TDS: Total Dissolved Solids (TDS) are the total amount of mobile charged ions, including minerals, salts or metals dissolved in a given volume of water, expressed as parts per million (ppm). TDS is directly related to the purity of water and the quality of water. High TDS results in undesirable taste which could be salty, bitter, or metallic in nature [8]. High TDS also indicate the presence of toxic minerals. The EPA's recommended maximum level of TDS in water is $500 \mathrm{mg} / \mathrm{litre}$ (500 ppm). During the study period, TDS values varied from $138 \mathrm{mg} / \mathrm{litre}$ to $148 \mathrm{mg} / \mathrm{litre}$.

TSS: Total suspended solids (TSS) give a measure of the turbidity of the water bodies. Suspended solids cause the water bodies to be turbid, milky or muddy appearance due to the light scattering from very small particles in the pond or river. Polluted waters are generally turbid and improvement is marked by greater clarity. Useful waters may be turbid, and many clean rivers are never clear because they contain fine suspended minerals that never settle. During the study period, TSS values varied from $32.44 \mathrm{mg}$ / litre to $104.32 \mathrm{mg} /$ litre.

Alkalinity: Alkalinity is important to aquatic organisms because it protects them against rapid changes in $\mathrm{pH}$. Wastewater can have higher alkalinity because it typically has higher concentrations of nutrients and ions, some with acid buffering properties, such as silicates and phosphates [9] (Singh et al., 2010). Alkalinity itself is not harmful to human beings but desirable limit of $100 \mathrm{mg} /$ litre is always required for domestic supply of water. The range of alkalinity ranged between $212.0 \mathrm{mg} /$ litre to $347.0 \mathrm{mg} / \mathrm{litre}$.

Hardness: As water moves through soil and rock, it dissolves very small amounts of minerals and contributes little bit of hardness in water body. Calcium and magnesium dissolved in water are the two most common minerals that make water hard [10] (Taylor, 1949). During the period of investigation water was ranged between 82.1 to $135.3 \mathrm{mg} /$ litre.

Chloride: Chloride is generally found in streams and wastewater. Chloride may get into surface water from several sources industries, municipalities, wastewater from water softening plant, agricultural runoff and produced water from gas and oil wells. The EPA Secondary Drinking Water Regulations recommend a maximum concentration of $250 \mathrm{mg} / 1$ itre for chloride ions and $250 \mathrm{mg} / 1$ itre for sulfate ions. The range of chloride ranged between 71.44 to $164.2 \mathrm{mg} /$ litre which was below the prescribed limit of IS standards. 


\section{Conclusions:}

The above mentioned results show severe deterioration of water quality of the selected pond. Keeping in view of all these results, it can be concluded that the selected pond water needs efficient treatment in increasing the dissolved oxygen, thus making it suitable for development of aquatic flora and fauna. Depletion of DO is due to enhanced by high concentration of organic matter of the selected pond.

Hence, it is recommended that water must be thoroughly analyzed and studied before being used for recreational purposes. These water bodies are not suitable for domestic and drinking purposes, proper treatment is necessary before their use for drinking purpose.

\section{Acknowledgement}

We are also grateful to Director, Garhwa Polytechnic, Garhwa for providing research facilities.

\section{Declaration of Conflict of Interest}

The authors declared no potential conflicts of interest with respect to the research, authorship, and/or publication of this article.

\section{Funding}

The author received no financial support for the research, authorship, and/or publication of this article.

\section{References:}

[1] Sargaonkar and V. Deshpande (2003). Development of an Overall Index of Pollution for Surface Water Based on a General Classification Scheme in Indian Context. Environmental Monitoring and Assessment, 89: 43-67.

[2] H. J. Vaux (2001). Water Quality Environment 43(3): 39.

[3] IS: 10500-1991: Indian Standards for Drinking Water Quality as per BIS specifications.

[4] APHA. (1995). Standard methods for the examination of water and waste water, $19^{\text {th }}$ Edition, Washington, D.C. 
[5] Usharani, K., Umarrani, K., Ayyasamy, P.M., Shanthi, K. and Lakshmanaperumalsamy, P. (2010). Physico chemical and bacteriological characteristics of Noyal River and ground water quality of Perur, Int. Journal .Appl. Sci. Environ Management. Vol 14(2) 29-35.

[6] Jonnalagadda, S.B., and Mhere, G. (2001). Water quality of the Odzi River in the eastern highlands of Zimbabwe. Water Research, 35 (10):2371-2376.

[7] Mishra, A., Mukherjee, A. and Tripathi, B.D. (2009). Seasonal and Temporal Variation $\mathrm{n}$ Physico chemical and Bacteriological characteristics of River Ganga in Varanasi, Int. J. Env. Res., 3(3):395-402.

[8] Abida, B. and Harikrishna (2008). Study on the quality of water in some streams of Cauvery River, E-journal of Chemistry, 5,(2):377-384.

[9] Singh,M.R., Gupta,A and Beeteswari, K.H. (2010). Physico chemical properties of water samples from Manipur river system, India, J.Appl.Sci. Environ. Management, Vol 14(4) 85-89.

[10] Taylor, E.W. (1949). The examination of water and water supplies. J. and Churchill Ltd. London. 